Marketing and Branding Research

WWW.CIKD.CA

\title{
The Effect of Uncertainty on Stock Returns and Risk-returns (Volatility) Relationship Across Military and Democratic Regimes in Pakistan
}

\author{
Zareen Zafar ${ }^{*}$, Danish Ahmed Siddiqui ${ }^{2}$ \\ ${ }^{1,2}$ Karachi University Business School, University of Karachi, Pakistan
}

\begin{abstract}
Keywords:

Pakistan Stock Market, Stock Returns, Risk Returns,

Military Regieme,

Democratic Regieme,

Ordinary Least Square,

Quantile Regression,

Uncertainty index

\begin{tabular}{l} 
Received \\
14 October 2020 \\
Received in revised form \\
26 October 2020 \\
Accepted \\
26 October 2020 \\
\hline
\end{tabular}

*Correspondence: zareenzafar2020@gmail.com

This research includes empirical results in making a consistent understanding of investor sagacity, investment returns, and behavioral stock market performance in the behavioral finance trend theoretical context. The data were collected using a long range of Returns data Pakistan's stock market Since June 1994 to December 2018 on the two economic segments known as the Military Period (1999-2008 and 2009-2018). Quantile Regression (QR) and Ordinary Least Square (OLS) carried out on future returns and risk-returns (volatility) where the independent variables Consumer Price Index (CPI), Gross Domestic Product (GDP), Money Market Rate (MMR), Discount Rate (DR) and Pakistan's Uncertainty Index were taken at annual data base. The findings indicated that $\mathrm{DR}$ and past returns significantly impact future returns. Other factors such as GDP, inflations, MMR and conditions of instability, however, had no major impact on returns. With regard to the military process, all variables such as past returns, GDP, discount and cash market levels, as well as volatility, had a major return impact. Whereas in the process of democracy, no macroeconomic factor affected those returns. With regard to volatility, CPI appeared to be the only factor that positively impacted the volatility of share prices, as well as each of the two phases while all other factors had no significant effect overall. In the event of instability, the variability and returns remained negligible for all stages except in the military process. The results suggested that macroeconomic policies tend to have a large effect on the return as contrasted with the political phase in the military period. That could be due to lower returns, which stick lowers mostly due to problems with governance. No policy stimuli may impact returns in that situation. In addition, the volatility case remained unclear given the variables discussed.
\end{abstract}


Stock markets are the best economic indicator and by pushing up the trade and development sector, they play a major role in the country's economy. Because of this, shareholders, firms, governments, and even financial institutions monitor stock markets closely and a country's economy depends on well-performing firms and corporate industries. Not only does the stock market show profitability, but also improve business progress and the strongest resource for investment firms to finance. Stock markets give us the ability to turn our savings into investments and transform the assets into liquid form again. It is the prime characteristic of the stock exchange. The stock market plays an important role in fostering the economic and commercial growth of a nation. The increase in the quantity and value of the capital markets is a consequence of the manufacturing sector growth. The significant role of the stock market generates opportunities for buyers and sellers to purchase and sell various securities, and shapes the amount of trade in a country. The financial sector gives investors protection by controlling and managing the economy.

Good trade represents a positive addition to a country's financial system. Stock markets that reduce the cost of financial intermediation; encourage investors to invest in relatively attractive stocks, and a well-performing stock market is an indicator of a well-performing economy (Greenwood \& Smith, 1997). According to Mohtadi and Agarwal (2001), the stock market represents the general economy. We observed if there is a good relationship between stock markets and the economic system, which implies stock market expectations and the economic circumstances of a country follow the same direction, that a well-performing financial sector is an indicator of a well-performing economy and badly managed equity markets which indicate the progress of a developing country. The successful operation of the financial markets also represents the entire wealth and growth of the economy. Stock market in any area is viewed as the hub of investment fund creation. That is also a symbolic of the economic situation of every region. Investors enter the capital markets mainly with a willingness to achieve income. The present research focuses solely on Pakistan's stock market where KSE 100 Index is dependent variable.

Pakistan Stock Exchange Limited ('PSX,' the 'Exchange') was assimilated in 1949 to the form of Karachi Stock Exchange (Guarantee) Limited as a guarantee-limited non-share company. The Exchange was corporatized in 2012, pursuant to the 2012 Stock Markets Act (Corporation, Demutualization and Integration), that is, it was transformed into a 'public limited-share corporation' and changed its name to Karachi Stock Exchange Limited ('KSE'). Through the trade, the rights of ownership were divided with the company from marketing rights. Exchange operations in 2015-16, along with Lahore Stock Exchange Limited 's associated assets and human resources after that, KSE was incorporated as well as Islamabad Stock Exchange Limited, and the Exchange emerged as a single national stock exchange under its current name, for example, Pakistan Stock Exchange Limited. Pakistan Stock Exchange appears to be the only worldwide trade for its owners, stakeholders and Customers.

Several other analysts were asked to analyze the relationship between inflation, exchange rates, treasury bills etc., economic determinants and the evolving stock index. To this end, it was found that there is a major connection between stock returns and macroeconomic events (Sajjad, Shafi, Jan, Saddat, Rehman, 2012).

Stock market analysts remain convinced that stock return volatility is due to past macroeconomic developments. Within a particular jurisdiction that will influence the other 
approximately capital markets, they also found that interest rate differences would have a significant effect on stock prices and their returns in each state because the interest rates increase. The stock market output of Pakistan will be affected by many eventually exposed factors; the financial sector in Pakistan has faced a variety of adverse political areas as a result of which the market impact has also been detrimental. Financial sector uncertainty is the free markets in the measurement of large stock markets for a specific timeframe. It is the dispersal and not the direction of price fluctuations (Ambrosio, 2007). Volatility can either be measured by standard deviation or difference with returns from the same sector or stock index (Debesh, 2013). Industry analysts are more concerned about standard deviations as it exemplifies the risk of serious return values (Schwert \& Seguin, 1990).). The standard deviation of a virtual all-share index in Nairobi was included in this analysis to calculate volatility on the financial markets. Stock exchange volatility continues to drop as stocks grow and fall as financial markets crash (Debesh, 2013).

\section{Discount Rate}

The discount rate is the interest rate on loans that the Fed's discount window lending program offers for banks. The share market model concerns the interest rates, the value of the stock market share, the maturity of the short- and long-term securities and the value of the investment as well as the growth factor, as well as the production and consumption model. There is equilibrium too, which is essentially an equilibrium, the point at which the supply quantity is equal to the quantity demands. Output and interest rates play a significant role in the discount adjustments as previous literature defined the different techniques, rules, and models. Due to the nominal and actual rates, they will never face inflation when prices are country-specified. Depends on progress in the stock market and fiscal policy (Simon \& Blume, 1994), changes in the discount rate will influence the currency exchange and asset return, whether they include information on short-term or long-term monetary policy goals. An increase in the discount would also certainly help draw more and more customers into the scheme that suggests a huge number of market change and the reaction of the firm to that. As a result of the lower short-run capital growth, current (spot) and expected short-term prices are increased. Business investment, corporate finance and valuation of both main and derivative securities are important for stock market volatility. Price stability is not related to existing market awareness, such as expected discount rate change announcements (Chen, Roll, \& Ross, 1986).

\section{Money Market Rate: Short-Term Interest Rate}

The finance sector may be understood as the short-term fund market, where loans and borrowings vary from overnight to year. It is a significant financial intermediary that helps businesses, banks, and financial institutions, government agencies and so on to fit the demands in the short and very short term. Davidson (1996) describes how all components relate to each other. He also thinks the interest rate has a significant impact on the economic development. The results were directed at long-term interest rates which play a crucial role in price dividend deviation ratios. The countries with lower interest rates have broad capital markets relative to places with higher interest rates. Developing countries tend to have low interest rates due to the excellent performance of their stock exchanges (Demirgüç-Kunt \& Levine, 1996). 
There are two significant factors that are involved in an economy's growth or decline, such as stock market and rate of interest. Interest rates have an effect not only on the financial markets but on fiscal policy too much. Interest rates affect the financial market more directly, an increase in interest rates allows investment companies to manage the value in terms, generally from the share market to fixed-income securities. Volatility of interest rates creates a drive straight from the financial markets to the financial system. As interest rate changes, an inverse proportion linked to stocks, stocks respond to the interest rate (Alam \& Uddin, 2009). Conceivably, the exchange-rate interaction with inventory may either be asserted as positive (depreciation of currency makes local firms more competitive, due to greater production as a result of higher stock prices), or negative (if output depends on imported input, production costs will increase as a result of capital inflows, thus reducing profit margins) and corresponding decreases in stock market returns and low or non-relationship (export-oriented market price rises with currency depreciation, as this high inflation also affects input costs, the effect would be nullified to some extent due to the increasing cost of production).

\section{Gross Domestic Product (GDP)}

The Gross Domestic Product is the most widely used measure of economic growth. It is a national accounting measurement tool, as it shows the total value of the finished goods produced inside the limits of the country in one year; irrespective of possession. GDP measures only the quality of products and services which are those goods and services influenced by their end user and are not used as inputs for other items. The products and services calculated incompletely would lead to double measuring of economic growth within a region. This separation is also reducing GDP contributions among businesses and individuals. A research by Boyd, Levine and Smith (2000) assisted inflation on investment in the financial industry.

Success in the finance market was calculated using the performance of the banking sector and the returns on the financial sector. The fluctuations in stock market results reflect the differences in economic activity. Stock markets play a critical role in economic development and in building the stable and also well-organized financial system of an economy. Haroon and Jabeen (2013) said that the stock market is a very well-organized entity that helps savers and lenders trade securities across borders. Companies enter the stock exchange in order to raise money to meet their financial requirements (Gans et al., 2011). In fact, a productive stock market is certainly part of a nation's economic and social climate. Ultimately, stock prices and business outcomes create an image and scenario of the direction of economic operation (Janor, Halid, \& Rahman, 2005). Pakistan's stock market is in a stage of expansion and that more progress is needed to boost its impact on the economy. In addition, the stock market has been volatile in the last 10 years, and financial crises in 2005, 2006 and 2008 (Haroon \& Jabeen, 2013). Global economic information, including money supply, interest rate, currency exchange rate in the economy, plays a vital role in stock returns.

\section{Consumer Price Index (CPI)}

The CPI target range of goods and services is planning to spend on consumer-related items for urban residents, domestically and internationally imported, such as experts, self-employed, the poor, the jobless, the elderly, and also urban wage earners and service workers. The CPI does not cover rural or low-income urban areas, agricultural communities, armed men, and people 
in facilities such as jails and facilities of psychiatry. The CPI struggles with food and beverages, lodging, clothes, transportation, medical care, culture, schooling, interaction and other personal products and services, such as tobacco and smoking, haircuts and funerals

Schwert (1989) stated that there are three theories that predict positive volatility and volume. Second, both price increases and sales cause new awareness if shareholders have diverse views. Therefore, if any investors use market volatility as data from which to make investment decisions, major price shifts cause large amounts of investment. Eventually, when there is a short-term 'demand pressure' due to illiquidity in secondary trading markets; large volumes of trade, primarily either purchasing or selling orders, cause demand fluctuations. The guidance of Schwert (1989) showed a big link between economic uncertainty and trade. And the assertion that stock market volatility was higher with higher trading activity soon arrived and there was little suggestion that excessive volatility would accompany potential growth rates in trade, with the exception of fluctuations in investment from 1920 to 1952. Carlton (1983) indicated that inflation would significantly adversely affect the amount traded. The degree of inflation appears to have been more closely associated with the amount shared, rather than with the unanticipated portion of inflation. A related explanation for a fall in trade resulting from higher prices has to do with the various kinds of products available in the future. Kandel, Ofer, and Sarig (1993) found that the variance in inflation expectation error declined in the era under study, with stock market. Traders understand the decline in the particular methods by constantly evaluating prices around the allocation of other traders' knowledge.

\section{Uncertainty}

The theory of classical genuine options postulates that ambiguity decreases investment actions (Antoshin, 2006). Accordingly, the research suggests negative effects of unpredictability and confusion on investment by Carruth, Dickerson, and Henley (2000). Belanová (2014) examined the impacts of uncertainty and irreversibility as decision factors for investments. It may also appear that interaction between such variables will generate potential costs and the adoption of the corresponding (real) alternative, and the widespread global market and organizational set-up conditions in fragmented developing world. Economies are also susceptible to uncertainties. The research accepts that the inverse relationship between uncertainty and investment persists in the face of indivisibility. Fernandez and Rodrik (1991) and Pindyck and Solimano (1993) said that political uncertainty appears to be reducing investment rates. It is expected that factors such as weak states, dysfunctional democratic structures, non-observance of the rule of law, poor law and order, corruption, uprisings, demonstrations, violence and frequent changes in political regimes will affect investment decisions (Sjaastad \& Bromley, 1997; Stewart \& Venieris, 1985). That has led to a dreary business environment. It is undermining business morale and rising business costs because land rights are not adequately enforceable. Julio and Yook (2012) address how corporate investment impacts global uncertainty. The study found that expenditure in election years decreased on average by 4.8 per cent compared to none-choice years. The current empirical evidence supports the notion of aggregation of investment rates that adversely affect political instability/ uncertainty. 


\section{Volatility}

Volatility is defined as the amount of uncertainty or risk surrounding the degree of fluctuations in the value of a stock. A high variance means the value of a safety can be potentially distributed over a wider range of values. Thus, the security price may shift considerably in either direction over a short period of time. In comparison, lower variance would result in lower value fluctuations over time. To encourage economic growth and development, the financial markets track savings for profitable investments. However, stock market volatility can be an obstacle in this process, especially in an emerging economy where high price volatility contributes to the erosion of market capital Stability. In fact, this is a clear and discerning term, implying an unexpected return due to unforeseen events leading to large price fluctuations with inconstant volatility. The financial markets therefore generate an unpredictable behavior which could scare the investors. Pakistan's stock market is extremely volatile, as it is highly sensitive and open to outside events and news. Business practices do not take time to disrupt. Pakistan's stock market is resilient, and easily recovers aftershocks.

Market volatility states the statistical calculation of return dispersion for a given security or market index; it is also a valid option. Higher volatility means higher market risk, in other words, volatility is measured by mean difference and differences of returns. Volatility means market ups and downs that any transition from excitement to ups and downs is volatility, and volatility never remains same in but tends to shift, and we go through cycles of high and low volatility. Volatility is also rising with events on the international economy and on the world, as well as a country like Pakistan with bad political conditions. In general, stock prices show nonlinear, and potentially unpredictable behaviour. Even so, some note that in the short run stock prices/returns are imperfectly accurate, but in the long run inconsistent and statistical distributions can measure the unpredictable returns. There are many variables in the Stock market that cause volatility. Likewise, monetary policy, inflation, interest rate, corporate income, financial stability, dividend policies, bond prices, and many other macroeconomic, social, and political variables. The researchers also propose the transmission of economic transmission of stock market volatility between friendly countries of different backgrounds (e.g., Pakistan and China). The evidence of reduced volatility following the introduction of Pakistan's financial liberalization policies is that the scale of stock trading induces volatility, and an asymmetric volatility is attributable to price and volume exposures. Although some note that volatility arises from the amount of trading that is controlled by the development of new information on the latest shares or some form of private series that is enshrined in market share prices.

\section{Problem Statement}

Policy instability is also known as regime instability, a category of financial risk where the future course of federal policy is unpredictable, rising risk leaders and leading companies and individuals to delay spending and investment until such time as this uncertainty has been identified as a Policy uncertainty that may refer to monetary and fiscal uncertainty, tax or regulatory law, or electoral instability which may affect political leadership. The role of the financial market across each nation's economic development is quite significant but the currency markets in Pakistan cannot play its role as it should, due to unpredictable circumstances, unfavorable economic policies and over-reliance on debt financing. For these 
reasons, therefore, the equity market cannot develop until 1980 but after that, in 1991, it starts playing its role much better than the previous one when foreign investors were invited to invest in Pakistan (Hussain \& Qasim, 1997). It is generally known as the uncertainty (both macroeconomic and political) may affect investment in the opposite direction. In developing countries like Pakistan, the phenomenon of instability is even more special due to fragile economic conditions and political disturbances. The impact of political instability may be more evident because most investment decisions in a country like Pakistan are taken on an opportunistic and public choice basis, not on economic grounds.

Macroeconomic uncertainty is very critical in investment decisions because if economic conditions are unpredictable, potential buyers do not have demand growth expectations and therefore continue to shy away from taking the risk of incurring large sunken costs if demand does not increase. Similarly, political instability/uncertainty often enforces unexpected investment costs as it generates the risk of unexpected economic policy adjustments, particularly the tax system and other fiscal and monetary policy events that can directly or indirectly affect the cost-benefit aspects of investment decision making. The existing collection of evidence indicates various measures of uncertainty and irreversibility depending on the form of data, the complexity of the information (such as aggregated vs. disaggregated and macro vs. micro information) and the scale of the economy. Macroeconomic uncertainty was calculated using inflation, real exchange rates and proxies of interest rates which adversely affect capital formation (Aryeetey et al., 1994; Pattillo, 1998). The percentage rate of inflation adjustment has also been used, in some situations, as an indicator of uncertainty. Unconditional variation or standard deviation may be used for instability but not uncertainty as a measure.

Throughout the past seventy years, investment activity in Pakistan has gone through various phases, as the country has a long history of macroeconomic and political instability. Political and Economic Uncertainty and Investment Behavior indicates that economic turmoil was internal factors such as the debt crisis of the 1990s, when rupees began to fall against the US dollar, and major changes in monetary and fiscal policy positions and structural reforms under the IMF adjustment programmes. Within this context, it is important to discover the degree to which economic and political uncertainties have vulnerable investment activity in Pakistan, while taking into account other (conventionally considered) elements of investment behaviour. Investment behavior focuses primarily on risk, irreversibility and uncertainty issues. In the literature of the late 1980s, the issue of investment irreversibility and the role of risk/uncertainty in investment purposes has gained attention.

\section{Gap Analysis}

The previous studies showed a variety of research at macroeconomic variables using various techniques to calculate their effect with different aspects on the stock market. This research was carried out on Ghana, Viatnam and Srilanka (Jayasundara, Rathnayake, \& Fernando, 2019). Studies conducted in Pakistan (Ali, 2014; Jameel \& Hayee, 2017; Khalid \& Khan 2017; Kibria et al., 2014) Checked the influence of these parameters on the monetary policy, such as exchange rates, interest rates and inflation, per capita GDP, savings, stock market performance. There have been other global forces such as the MSCI World Index and the six months LIBOR index (Rizwan \& Khan, 2007). Nazir et al. (2014) explored the effects of incidents of various nature such as political, natural and terrorist calamities. In Several Studies, political instability, 
financial convergence on volatility in stock returns has discussed. Abbas, Ahmed, and Husain (2019) analyzed the effects of economic stability and economic and financial uncertainty on overall investment activities in Pakistan.

Yet no such research on Pakistan focused on the element of uncertainty, and its effect on returns conversely. In earlier findings, the effect of the above variables on returns and volatility incorporated into a single framework has not been examined. Above all, no such attempt has been made to split and examine the conduct of return and instability surrounding uncertainty separately for both dictatorship and democratic form of governance. We have used the perception-based indices of uncertainty developed by Ahir et al. (2018), to add behavioral ambiguity dimension. Consequently, this work is a unique attempt to provide a good image of Behavioral Finance Perspectives on Pakistan Stock Market Performance with Effect of Uncertainty on Stock Returns and Relationships (Volatility) across Military and Democratic Regimes.

\section{Research Objectives}

This analysis aims to estimate stock returns on which extensive work has been carried out over the past 24 years by analyzing stock return literature using OLS and QR data. The analysis is focused on the Efficiency measures of the Stock Market of Pakistan, using Quantile Regression as well as Ordinary Least Square, with the effect of political changes on stock return results. OLS and QR projections of potential returns and uncertainty were performed in this analysis by considering independent variables GDP, MMR, DR, CPI, and Pakistan Uncertainty Index. The dependent variable is KSE 100 INDEX Yearly Stock Returns based data from June 1994 to Dec 2018. The data was divided into three parts called Overall, Military Regime and also Democratic Regime. The average estimate based on mean OLS and QR provides a separate place about the nature of returns on stocks. This study shows the minimal rational investors as proxies by exploiting fundamental and behavioral uncertainties in their decision to invest in stocks.

\section{Research Questions}

What is the effect of Uncertainty on Returns for Future and Volatility?

Do Macroeconomic variables show different results on different segmented data?

Do Macroeconomic Variables Keep high importance regarding the Criteria of Stock Market? Can volatility affect stock market growth with regard to Behavioral Finance Perspectives?

\section{Significance of the Study}

The outcome provides the complexity and intensity of risk portfolio diversification within Pakistani stock between stock returns and other economic variables other than price. Since the stock returns of various companies, the return on the market varies across companies and in many cases acts differently under the same, but relevant, market circumstances. Political economy can be used as a tool for tracking anticipated returns on capital markets in terms of risk premium and volatility. This research is of great importance to fund managers and investors when making decisions about their investments. The findings in this study can also be of benefit to legislative and compliance authorities. The essence of the relationship between political uncertainty and stock market provides valuable knowledge for choices in equity. 


\section{Literature Review}

Various studies examined macroeconomic factors that affect stock yields. For example, Addo and Sunzuoye (2013) explored the complex impact of macroeconomic variables like money supply, Treasury bill (interest rate proxy), inflation rate, exchange rate and oil prices, and the stock market in Ghana. The result showed that some of the macroeconomic variables have a long-term correlation with the stock market. They calculated the effect of macroeconomic variables on CSE's all-share price index (ASPI) for Sri Lanka (Jayasundara et al., 2019). The results indicated the cumulative impact of macroeconomic variables on ASPI in Sri Lanka.

As for Pakistan, observing the relationship between capital structure and the interest rate (Pakistani economy) (Hamdan, 2014) shows that the interest rate has an adverse impact on the stock market. FaridUllahet Al (2014) examined the effect of monetary policy on the stock market in Pakistan. They took advantage of three main economic determinants: exchange rate, interest rate and inflation. It is found that both the rate of exchange and the interest rate have a negative relationship with Pakistan's stock market while the inflation rate does not establish a situation that affects the stock market in Pakistan. For shorter versions of the time, specific observations were made. The impact of macroeconomic variables (inflation rate, exchange rate and interest rate) was analyzed on stock-market returns for Pakistan (Ilahi, Ali, \& Jamil, 2015). Research has shown that Karachi Stock Exchange 100 indexes are not associated with exchange rate, inflation rate and interest rate stock returns. The impact of interest rates, exchange rates and inflation levels on Pakistan's economic performance has been empirically evaluated using data from the annual time series representing the periods 1991-2017 (Khalid $\&$ Khan, 2017). The empirical results showed a negative and substantial effect on the interest rate index by applying the ARDL model; whereas, exchange rates and inflation have a significant long-term influence on stock market volatility. There were five macroeconomic variables considered to provide an impact such as Inflation, GDP per capita, export taxes, money supply and the rate of exchange on the KSE 100 index in Pakistan (Kibria et al., 2014). Regression analysis findings indicated that inflation, exchange rates, cash supply, Income and Exports per capita increases have a significant positive impact on the KSE 100 index. Waseem (2014) examined the potential impact of the economic indicators on Pakistani stock market gains, including fiscal and monetary (interest) policies and inflation rates. The findings showed a clear negative relationship between the interest rate and tax collections and Pakistan's stock market index, while inflation rate and government spending had a favorable and important relationship to Pakistan's stock market index.

The outcomes included even financial ones. Nazir et al. (2014) investigated the impact of events of a different kind on financial sector share prices in Pakistan such as financial, natural disasters and terrorism. The research evidence clearly showed that event had a major effect on Karachi Stock Exchange's share prices. The other study explored the impact of political instability on Pakistan's economy and its instability (Tabassama, Hashmi, \& Rehman, 2016). Only terrorism has been found to have a major negative impact on the mean equation of dependent variable between violence, elections, regime and assaults. The variance equation indicated important negative effects of elections and regimes on the variations in GDP. Concerning stock price volatility, Esqueda, Assefa, and Mollick (2012) analyzed stock market volatility Measured either by "beta variance" or a standard deviation in stock yield over 19952007. Some supports are seen for increases in financial convergence which would raise total 
volatility of stock returns for representative emerging markets, with almost no impact on advanced markets.

A survey of 74 countries examined the relationship between democratisation rates and stock-market returns (Lei \& Wisniewski, 2018). This paper explored how a more than four decades study of 74 countries connects military governance to market returns. Note that in modern democracies, dollar-denominated returns on stock appear to be slightly higher, and this will not seem to advantage from a default risk. In addition, for autocracies, risk of unpredictability tends to be greater than ceteris paribus. Eventually, a political structure helps the general public to invest in private pensions in the stocks. This raises demand for domestic equity while raising market valuations.

\section{Political Stability}

It has been recorded that an increase in market volatility returns as the degree of visibility to political risk falls within the company. Political instability will occasionally tend to aid certain industries and hamper the returns of other industries. After receiving votes from the electorate and government positions, every political economy is willing to handle the policies that follow foundation of their Parliament (Hibbs, 1977). This insight can help to understand volatility in stock prices as a response to changes in policy. Investor is watching the forthcoming and fresh government's preferred policies which can impact their portfolios. Likewise, the political risks also contribute to the country's economic condition and these factors also clarify stock price behavior. These include international politics, social harmony, religious differences, etc. The Change of Government is simply a shift of power from one people's society to the next where economic development is the prime objective. The complex political climate is undermining the regulatory bodies and discussing those effects. The essence of the connection among political uncertainty and stock market failure offers useful information for investment choices. Long-term stock price shocks are typically caused by political instability, whereas short-term stock price imbalances are brought about. Political instability and productivity expansion are usually seen as inversely proportional, which is also clarified if the political conditions are unstable; then income activity will be low, and vice versa, and then the personalityencouragement frame structure

As for Pakistan, Malik and Temple (2009) looked at the impact of political uncertainty on stock market volumes and returns. It was for that reason that data were taken from 18 February 2008 to 18 February 2009. The specifics were subdivided into General Musharraf's preresignation period and Musharraf's post-resignation time. Data will be analysed using cooperative methods. There was also a good relationship between size and returns. It was also noticed that in the post-resignation time, the partnership was highly relevant. In the postresignation period, the relationship between stock market and returns which was .49 in the preresignation era increased to .79 . This is the impact of the political system of public events until early 2008. The stock market in the past, when Musharraf resigned, rose on August 18 and declined after 2-3 days. The explanation for that decline may be the investor's perceived political condition at the time. Investors putting a stop to their savings raised questions on the market.

Clark, Masood, and Tunaru (2008) studied how political uncertainty has impacted the financial markets in Pakistan. This article evaluates the risk capital rates associated with the 
stock market in Pakistan and replied if that relationship has existed in the past and what it is likely to be in the future. This research aimed to check how policy changes influence investment returns. Hussain and Qasim (1997) published a 50-year financial-market study of Pakistan. Because of many political errors, the company, as per their report, experiences considerable volatility at periodic times. In the 1960s, the stock market was gaining momentum but after the war of 1965 and the 1971 secession of Bangladesh, along with policies of government nationalization, Equity Market faced a complicated challenge. The stock market regained momentum from 1970 to 1980 , when the government started relying heavily on the private industry. In 1991, stock markets were done publicly to foreign investors as part of the modernization of the capital markets around the world. This showed that the financial markets at the time was at a high level, and greatly improved. But the market later struggled to sustain its progress due to various factors such as inflation, market volatility, rising budget deficits and unemployment levels. It was also found that consumer behavior changes over a specified period, and that the key explanation for this new appearance is flaws in political systems.

\section{Uncertainty with Stock Returns}

Investors are capitalizing on their stock market investments with the goal of earning some profits. This income is referred to as "stock returns," which may be in the form of profits gained from sales of shares or collected dividends. Such dividends are paid by the gains received to shareholders; can be on a quarterly, half-annual, annual, etc. The stock prices or returns are expected to be influenced by different threats that arise within a country and incidents that often arise around the world.

Dividend and capital appreciation include returns on the money capitalized in stocks. Both systemic and unsystematic threats affect those returns. The macroeconomic variables are included in the systemic risk, and the unsystematic risk involves firm particular factors. Returns on stocks are very significant for the country's political turmoil, economic crises, natural disasters like earthquake, cyclones, impacting fluctuations in global oil prices, inflationary impacts, and changes in government policies, standards, and regulations. Stock market returns are one area of finance where psychological trends are mostly assumed to contribute to market results and returns, although there are many different views of observation. Market return is determined by stock price increase.

\section{Uncertainty Index}

We used the Pakistan Uncertainty Index as independent variable developed by Ahir et al. (2018) representing 143 nations. This is a distinct from the frequency of the term "uncertainty" in the country reports for the quarterly Economist Intelligence Unit. The index measures uncertainty about both short-term (e.g., uncertainty generated by the United Kingdom referendum in favor of Brexit) and long-term problems related to economic and political developments (e.g., turmoil caused by the eventual withdrawal of multinational forces in Afghanistan, or tensions between North and South Korea. EIU country studies the approach to build the WUI that is to count the number of uncertain times/tries reported. The raw counts are also multiplied by the minimum word count in each study to make the WUI comparable across the countries. 


\section{Graphical Presentation between Returns and Uncertainty Index}

Figure 1 displays quarterly uncertainty index and returns for the 1996-2018-time frame. The market experiences sequences of ups and downs that can be affected by various factors in politics, social, cultural, and technology. Uncertainty index behavior is optimistic with everincreasing and rising patterns. The Retunes reveals both positive and negative behaviors with rising and deteriorating patterns because of the country's unstable economic conditions.

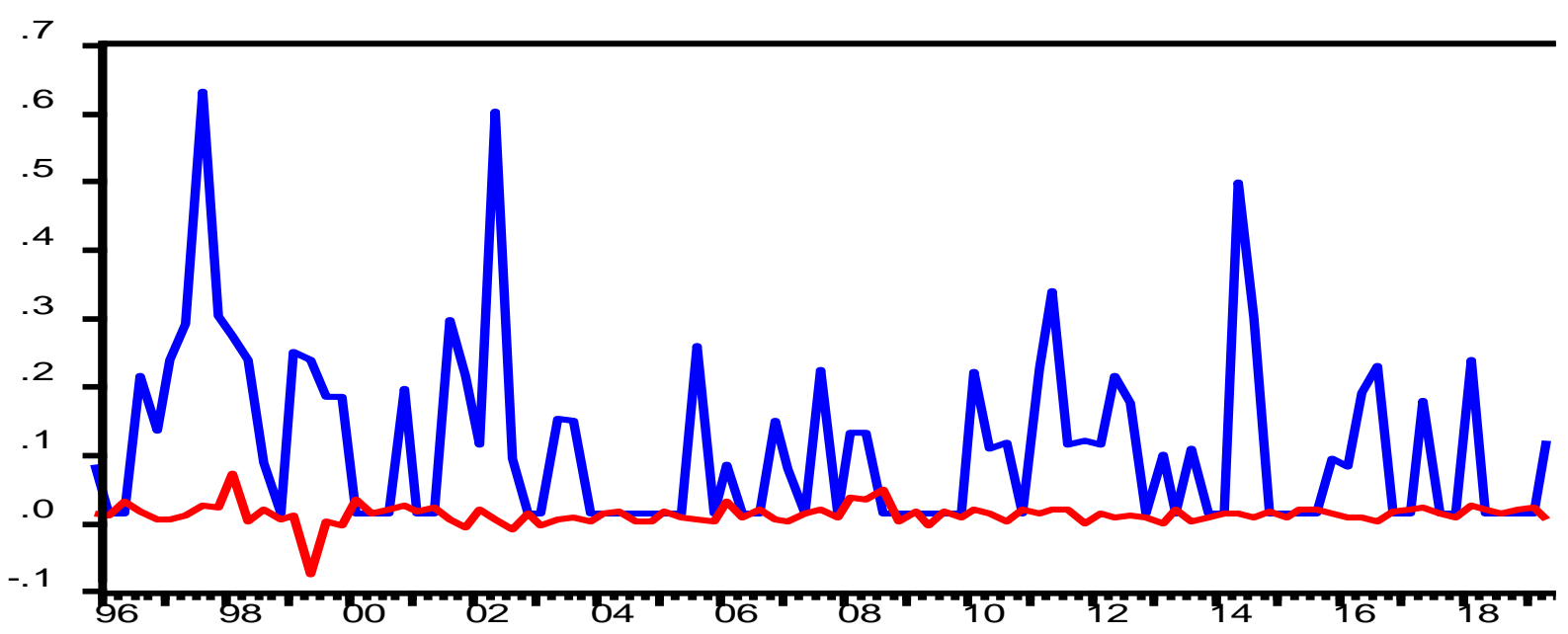

Figure 1. Returns and Uncertainty index graph.

\section{Separate Graphs of Uncertainty Index and Returns}

Figure 2 and 3 quarterly outlined returns and the Index of Uncertainty for the period 19962018, respectively. The Returns indicates both positive and negative behaviors with growing and decreasing patterns while the uncertainty index behavior is positive with rising and declining patterns.

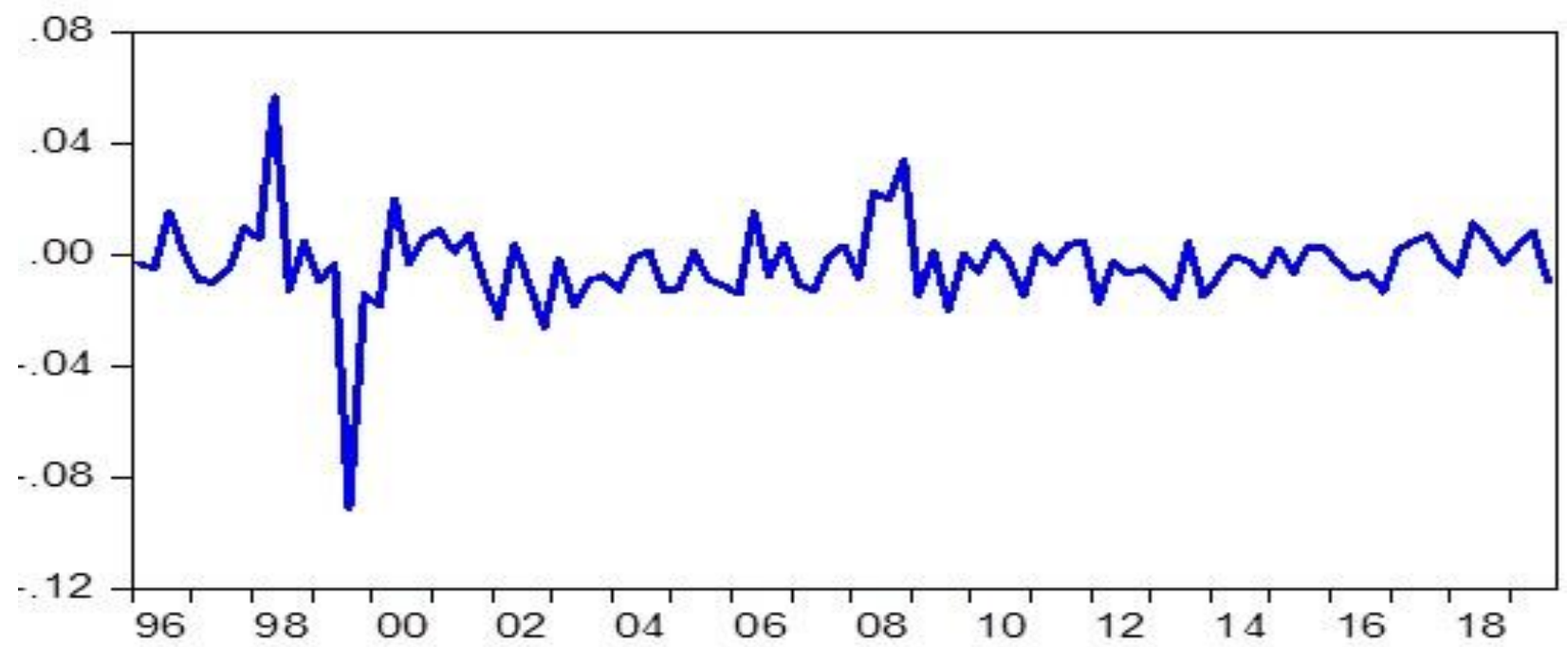

Figure 2. Returns 


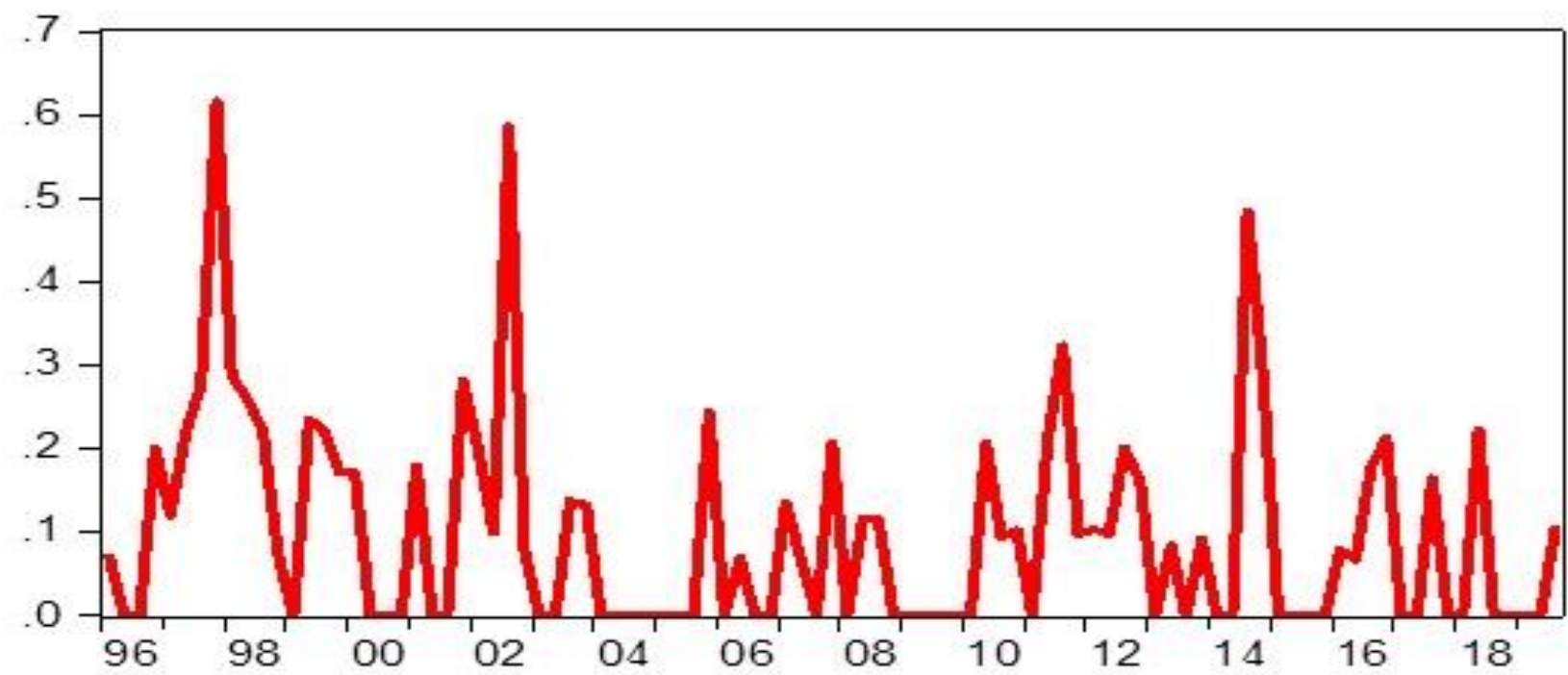

Figure 3. Uncertainty index

\section{Method}

We measured the asymmetric dynamic nature of the risk-return relationship for potential returns and volatility returns by using Ordinary Least Square (OLS) and Quantile Regression (QR). From June 1994 to December 2018, the data were used as an annual basis for all macroeconomic variables except for the Uncertainty Index since 1996. The macroeconomic variables I Money Market Rate, Discount Rate, Consumer Price Index, GDP and Uncertainty Index were used as independent variables while Future Returns and Volatility Returns were used as dependent variables

\section{Calculations for Ordinary Least Square (OLS)}

Standard, least square regression is among the most widely used statistical methods. It is a parametric model, however, which relies on assumptions that are often not met. The study of OLS is based on Gaussian assumption. For each case I the conditional distribution [yi] is given by $y i=(\beta 1, \beta 2, \ldots, \beta p)$ where $y=\beta 1 x i, 1+\beta 2 x i, 2+\cdots+\beta i, p x i, p \beta=(\beta 1, \beta 2, \ldots, \beta p), T$ are parameters of $\mathrm{p}$ regression (constant over all cases), Ei Residual (error) variable (varies over all cases)

$$
\mathrm{Y}_{\mathrm{iols}}=\beta_{0}+\beta_{1} \mathrm{X}_{\mathrm{I}}+\varepsilon \mathrm{I}
$$

\section{Calculations for Quantile Regression (QR)}

As shown in Figure 4, quantile regression models the connection between multiple (independent) response variable and various percentiles (or "quantiles") of a (dependent) target variable, most commonly the mean. This has two major advantages over Regression of Ordinary Least Squares: Quantile regression gives an estimate about the target variable distribution, and appears to avoid the influence of outer observations. Quantile regression is commonly used in market analysis, such as biology, agriculture, and financial economics. 


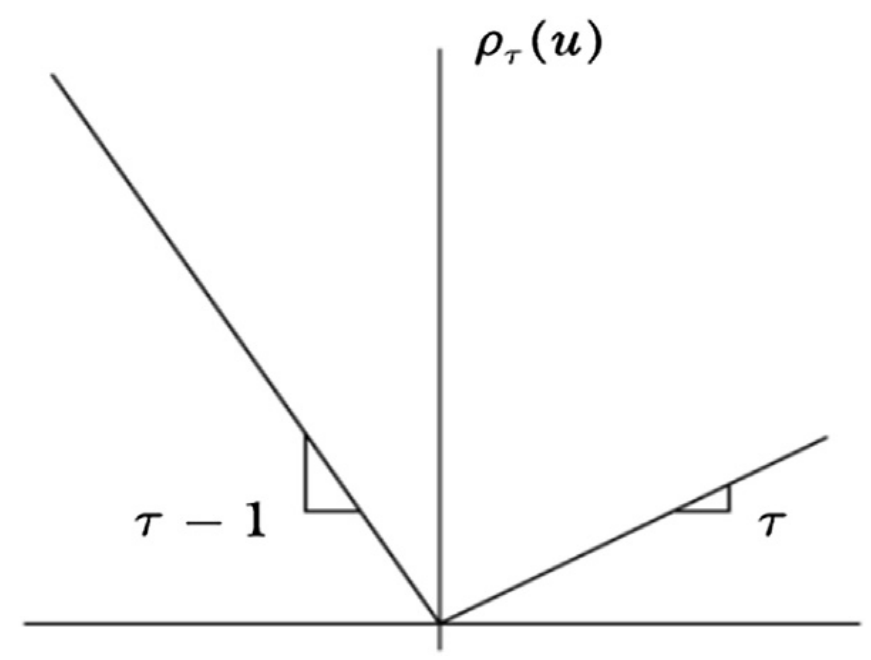

Figure 4. Quantile regression p function.

Source: Adapted by Koenker and Hallock (2001).

Quantile regression is a statistical approach used within a regression system to model quantiles (i.e., percentiles). Although median regression, a good example of quantile regression, dates back as early as 1760 , Koenker's $(2015,2017)$ works have in the last decade often get quantile regression into the empirical world $(2,3)$. Though statistical analysis was more of a concern, it appears to be underused in medical research and has since been incorporated in popular statistical packages. Quantile regression is a statistical method for the approximation of conditional quantile functions. Just as traditional linear regression methods based on minimizing the square residual sums enable models for probability distribution parameters to be calculated. Quantile regression approaches include a basis for estimating models of conditional median function, and a wide spectrum of other conditional quantile functions. By applying techniques to the estimation of conditional mean variables to estimate up an entire family of key values functions, quantile regression could provide a more detailed quantitative models of probabilistic relationships between random variables. It also addresses various aspects of the relationship between the two variables and the outcome variable (Koenker, 2015). Consequently, distributions which differ not only by their values but also (or even) by their lower or upper parts, while modeling only the mean, as done in linear regression, can miss important aspects of the relationship between the outcome and its predictors. Quantile regression describes how to design each quantile, including the median (i.e., .5), of the following hypothesis. Even though measurement of the regression coefficients differs slightly from linear regression (because it is focused on minimizing the number of calculated absolute residuals rather than square residuals). Quantile regression can be applied in the same way, allowing for the adjustment of possible confounders and the approximation in terms of dealing and variable selection. In this way, the statistical exceptions are more reliable and give far more detail on the fundamental associations. A study of the non-Gussian QR computes the autocorrelation of market returns. The equation is:

$\mathrm{Y}_{\mathrm{iQR}}=\beta_{0}+\beta_{1} \mathrm{X}_{\mathrm{I}}+\varepsilon \mathrm{I}$ 


\section{Results}

\section{Future Returns}

OLS and QR results are outlined in Table 1 for future return analysis. It seems to provide a clear understanding and importance of evaluating the relationship between risk and return on potential returns. The overall mechanism inside the model and the democratic phase are negligible. In the military phase it is essential to execute oneself. The QR provides a heterogeneous, continuous sequence of risk factor returns. The analysis carried out calculations for all possible quantiles (i.e., .1, .2, .3, .4, .5, .6, .7, .8, and .9), plus two extreme quantiles (i.e., .05 , and.98). Overall, major trends are found in lower quantiles up to .2 and occur positively in upper quantiles from .8 onwards. In general, it is only in military phases, and certain principles that show significance. Even so, the non-Gussian QR substitute research stated that the relationship between autocorrelations is asymmetric. Extreme loss relationships are positive and insignificant, positive and essential in extreme gains with few variables being negligible, and positive and negligible in complete regression at median points. In severe losses the relationships are poor and marginal, positive and significant in severe gains with few small variables, and optimistic and marginal median points in the process of democracy. The relationships are positive and significant in extreme losses, in extreme positive and significant wins, and significantly positive median points in the military phase. This suggests that riskreturn behavior is of great importance in the model's military phase. 
Table 1

Asymmetric Dynamic Behavior of Risk-Returns Relationship (Future Returns)

\begin{tabular}{|c|c|c|c|c|c|c|c|}
\hline \multirow[t]{3}{*}{ Data Segmentation } & \multirow[t]{3}{*}{ Variables/Statistic } & \multirow[t]{3}{*}{ OLS } & \multicolumn{5}{|l|}{ QR } \\
\hline & & & Lower & & Middle & & Upper \\
\hline & & & .05 & .2 & .5 & .8 & .98 \\
\hline \multirow{11}{*}{$\begin{array}{l}\text { Overall } \\
\mathrm{R}_{\mathrm{t}}=\alpha_{\mathrm{t}}+\beta_{1} \mathrm{R}_{\mathrm{t}-1}+\beta_{2} \mathrm{GDP}_{\mathrm{t}} \\
+\beta_{3} \mathrm{DR}_{\mathrm{t}}+\beta_{4} \mathrm{CPI}_{\mathrm{t}}+ \\
\beta_{5} \mathrm{MMR}_{\mathrm{t}}+\beta_{6} \mathrm{UI}_{\mathrm{t}}+\varepsilon_{\mathrm{t}}\end{array}$} & LAGRT & $0.02 * *$ & .30 & .22 & .18 & $.05 * * *$ & $.00 *$ \\
\hline & GDP & 0.39 & .94 & .93 & .92 & .92 & .88 \\
\hline & DR & $0.03 * *$ & .53 & .45 & .44 & .38 & $.04 * *$ \\
\hline & $\mathrm{CPI}$ & 0.56 & .82 & .77 & .72 & .70 & .62 \\
\hline & MMR & 0.58 & .50 & .40 & .37 & .32 & $.07 * * *$ \\
\hline & UI & 0.21 & .31 & .18 & .13 & $.08 * * *$ & $.00 *$ \\
\hline & Adjusted R-squared & 0.27 & .12 & .12 & .12 & .12 & .12 \\
\hline & JB Test & 3.52 & & & & & \\
\hline & BPG Test & 0.53 & & & & & \\
\hline & BG-LM Test & 0.42 & & & & & \\
\hline & VIF Test & $1.930-45.472$ & & & & & \\
\hline \multirow{11}{*}{$\begin{array}{l}\text { Military Phase } \\
\mathrm{R}_{\mathrm{t}}=\alpha_{\mathrm{t}}+\beta_{1} \mathrm{R}_{\mathrm{t}-1}+\beta_{2} \mathrm{GDP}_{\mathrm{t}} \\
+\beta_{3} \mathrm{DR}_{\mathrm{t}}+\beta_{4} \mathrm{CPI}_{\mathrm{t}}+ \\
\beta_{5} \mathrm{MMR}_{\mathrm{t}}+\beta_{6} \mathrm{UI}_{\mathrm{t}}+\varepsilon_{\mathrm{t}}\end{array}$} & LAGRT & $0.03 * *$ & .61 & .43 & .25 & .10 & $.03 * *$ \\
\hline & GDP & $0.01 * *$ & $.05 * * *$ & $.02 * *$ & $.005^{*}$ & $.0009 *$ & $.002 *$ \\
\hline & DR & $0.05 * * *$ & .14 & $.05 * * *$ & $.01 * *$ & $.004 *$ & $.01 * *$ \\
\hline & $\mathrm{CPI}$ & $0.005^{*}$ & $.04 * *$ & $.01 * *$ & $.003 *$ & $.00^{*}$ & $.001 *$ \\
\hline & MMR & $0.01 * *$ & $.04 * *$ & $.01 * *$ & $.004 *$ & $.001 *$ & $.004^{*}$ \\
\hline & UI & $0.01 * *$ & $.06 * * *$ & $.02 * *$ & $.005^{*}$ & $.001 *$ & $.002 *$ \\
\hline & Adjusted R-squared & 0.96 & .73 & .73 & .73 & .73 & .73 \\
\hline & JB Test & 3.01 & & & & & \\
\hline & BPG Test & 0.46 & & & & & \\
\hline & BG-LM Test & 0.51 & & & & & \\
\hline & VIF Test & $\begin{array}{l}1.625- \\
2571.987\end{array}$ & & & & & \\
\hline \multicolumn{8}{|l|}{ Democracy Phase } \\
\hline \multirow{11}{*}{$\begin{array}{l}\mathrm{R}_{\mathrm{t}}=\alpha_{\mathrm{t}}+\beta_{1} \mathrm{R}_{\mathrm{t}-1}+\beta_{2} \mathrm{GDP}_{\mathrm{t}} \\
+\beta_{3} \mathrm{DR}_{\mathrm{t}}+\beta_{4} \mathrm{CPI}_{\mathrm{t}}+ \\
\beta_{5} \mathrm{MMR}_{\mathrm{t}}+\beta_{6} \mathrm{UI}_{\mathrm{t}}+\varepsilon_{\mathrm{t}}\end{array}$} & LAGRT & 0.12 & .29 & .30 & .40 & .19 & $.07 * * *$ \\
\hline & GDP & 0.29 & .80 & .78 & .79 & .63 & .40 \\
\hline & DR & 0.93 & .99 & .99 & .99 & .99 & .97 \\
\hline & CPI & 0.21 & .69 & .68 & .61 & .36 & $.08 * * *$ \\
\hline & MMR & 0.32 & .74 & .73 & .81 & .71 & .59 \\
\hline & $\mathrm{UI}$ & 0.75 & .42 & .34 & .19 & .04 & $.009^{*}$ \\
\hline & Adjusted R-squared & .06 & -.10 & -.10 & -.10 & -.10 & -.10 \\
\hline & JB Test & 1.06 & & & & & \\
\hline & BPG Test & 0.50 & & & & & \\
\hline & BG-LM Test & 0.01 & & & & & \\
\hline & VIF Test & $3.112-807.867$ & & & & & \\
\hline
\end{tabular}

Note. OLS uses robust standard Neweye West estimators to modify the residuals for heteroskedasticity and/or autocorrelation issues for the ordinary least square estimation. The QR is calculated for autoregressive quantile regression using estimators from the Huber Sandwich that are accurate under independent but non-identical sampling. The ***, and *** asterisks indicate a significant level of $1 \%, 5 \%$, and $10 \%$ and between. The acronym of the variables reads as described in the following; Return (Rt); Lag Returns (Rt-1); GDPt; Money Market Rate (MMRt); Discount Rate (DRt); Uncertainty Index (UI) and Consumer Price Index (CPIt). Diagnostic statistics; normality test (JarqueeBera test); heteroscedasticity test (Breusche Pagane Godfrey test); serial correlation (BreuscheGodgrey LM test); and multicollinearity test (centered inflation factor test). The Wald test is conducted to evaluate 10 separate quantiles from q0.10 to q0.90 on the quantile slope equality. For QR, we only record 5 quant les estimation results describing extreme lower, medium and extreme upper quantiles in line with our emphasis and due to space constraints while we measured all other quantiles (i.e., q0.10 to q0.90).

\section{Volatility Returns}

The results of OLS and QR tests for the volatility returns are shown in Table 2. The average model is negligible which means that the relationship returns in model is negligible volatility. The democratic process is irrelevant in the model. It is vital to implement the military process at the upper quantiles, with few minor variables. The QR provides a heterogeneous, coherent series of risk factor reversals. The study carried out estimates of all possible quantiles (i.e., .1, $.2, .3, .4, .5, .6, .7, .8$, and .9 ) plus two extreme quantiles (i.e., .05 and .98). Overall, important trends are observed in lower quantiles up to .2 and upper quantiles starting from .8. OLS seems amazing in all phases. Besides this, the alternative non-Gussian $\mathrm{QR}$ analysis showed asymmetric relationship between autocorrelations. The associations in extreme losses are 
positive and insignificant, positive and insignificant in extreme gains and positive and insignificant in median-point regression in general. Relationships in extreme losses are positive and insignificant, positive and insignificant in extreme wins along with positive and insignificant in the course of democracy and in midpoints. The relationships in extreme losses are positive and insignificant, positive and essential in extreme wins and positive and marginal median points in the military process.

Table 2

Asymmetric Dynamic Behavior of Risk-Returns (Volatility) Relationship

\begin{tabular}{|c|c|c|c|c|c|c|c|}
\hline \multirow{3}{*}{ Data Segmentation } & \multirow{3}{*}{ Variables/Statistic } & \multirow{3}{*}{ OLS } & \multicolumn{5}{|l|}{ QR } \\
\hline & & & Lower & & Middle & & Upper \\
\hline & & & .05 & .2 & .5 & .8 & .98 \\
\hline \multirow{11}{*}{$\begin{array}{l}\text { Overall } \\
\mathrm{R}_{\mathrm{t}}=\alpha_{\mathrm{t}}+\beta_{1} \mathrm{R}_{\mathrm{t}-1}+\beta_{2} \mathrm{GDP}_{\mathrm{t}}+\beta_{3} \mathrm{DR}_{\mathrm{t}} \\
+\beta_{4} \mathrm{CPI}_{\mathrm{t}}+\beta_{5} \mathrm{MMR}_{\mathrm{t}}+\beta_{6} \mathrm{UI}_{\mathrm{t}}+\varepsilon_{\mathrm{t}}\end{array}$} & LAGRTV & 0.97 & .69 & .63 & .64 & .6 & .65 \\
\hline & GDP & 0.12 & .65 & .63 & .63 & .54 & .24 \\
\hline & DR & 0.43 & .91 & .88 & .85 & .77 & .61 \\
\hline & CPI & $0.03 * *$ & .47 & .45 & .48 & .37 & .11 \\
\hline & MMR & 0.68 & .97 & .97 & .96 & .95 & .92 \\
\hline & UI & 0.72 & .92 & .90 & .88 & .80 & .58 \\
\hline & Adjusted R-squared & 0.20 & .11 & .11 & .11 & .11 & .11 \\
\hline & JB Test & 2.31 & & & & & \\
\hline & BPG Test & 0.53 & & & & & \\
\hline & BG-LM Test & 0.58 & & & & & \\
\hline & VIF Test & $\begin{array}{l}1.493- \\
27.756 \\
\end{array}$ & & & & & \\
\hline \multirow{11}{*}{$\begin{array}{l}\text { Military Phase } \\
\mathrm{R}_{\mathrm{t}}=\alpha_{\mathrm{t}}+\beta_{1} \mathrm{R}_{\mathrm{t}-1}+\beta_{2} \mathrm{GDP}_{\mathrm{t}}+\beta_{3} \mathrm{DR}_{\mathrm{t}} \\
+\beta_{4} \mathrm{CPI}_{\mathrm{t}}+\beta_{5} \mathrm{MMR}_{\mathrm{t}}+\beta_{6} \mathrm{UI}_{\mathrm{t}}+\varepsilon_{\mathrm{t}}\end{array}$} & LAGRTV & 0.20 & .59 & .43 & .22 & $.05 * * *$ & $.003 *$ \\
\hline & GDP & 0.83 & .74 & .73 & .56 & .29 & $.01 * *$ \\
\hline & DR & 0.63 & .72 & .63 & .43 & .17 & $.003^{*}$ \\
\hline & CPI & 0.92 & .68 & .63 & .43 & .16 & $.003^{*}$ \\
\hline & MMR & 0.46 & .66 & .57 & .37 & .13 & $.002 *$ \\
\hline & UI & 0.73 & .88 & .86 & .78 & .59 & .12 \\
\hline & Adjusted R-squared & 0.38 & -.27 & -.27 & -.27 & -.27 & -.27 \\
\hline & JB Test & 0.16 & & & & & \\
\hline & BPG Test & 0.10 & & & & & \\
\hline & BG-LM Test & 0.27 & & & & & \\
\hline & VIF Test & $\begin{array}{l}2.250- \\
39.661 \\
\end{array}$ & & & & & \\
\hline \multirow{11}{*}{$\begin{array}{l}\text { Democracy Phase } \\
\mathrm{R}_{\mathrm{t}}=\alpha_{\mathrm{t}}+\beta_{1} \mathrm{R}_{\mathrm{t}-1}+\beta_{2} \mathrm{GDP}_{\mathrm{t}}+\beta_{3} \mathrm{DR}_{\mathrm{t}} \\
+\beta_{4} \mathrm{CPI}_{\mathrm{t}}+\beta_{5} \mathrm{MMR}_{\mathrm{t}}+\beta_{6} \mathrm{UI}_{\mathrm{t}}+\varepsilon_{\mathrm{t}}\end{array}$} & LAGRTV & 0.69 & .68 & .58 & .64 & .66 & .12 \\
\hline & GDP & 0.42 & .90 & .86 & .86 & .86 & .59 \\
\hline & DR & 0.23 & .88 & .83 & .76 & .71 & .11 \\
\hline & CPI & 0.17 & .79 & .71 & .70 & .68 & .23 \\
\hline & MMR & 0.39 & .84 & .79 & .85 & .87 & .54 \\
\hline & UI & 0.14 & .96 & .94 & .91 & .87 & .70 \\
\hline & Adjusted R-squared & 0.34 & .07 & .07 & .07 & .07 & .07 \\
\hline & JB Test & $10.78^{*}$ & & & & & \\
\hline & BPG Test & 0.47 & & & & & \\
\hline & BG-LM Test & 0.03 & & & & & \\
\hline & VIF Test & $\begin{array}{l}2.290- \\
26.849\end{array}$ & & & & & \\
\hline
\end{tabular}

Notes. OLS uses robust standard Neweye West estimators to modify the residuals for heteroskedasticity and/or autocorrelation issues for the ordinary least square estimation. The QR is calculated for autoregressive quantile regression using estimators from the Huber Sandwich that are accurate under independent but non-identical sampling. The $* * *$, and $* * *$ asterisks indicate a significant level of $1 \%, 5 \%$, and $10 \%$ and between. The acronym of the variables reads as described in the following; Return (Rt); Lag Returns (Rt-1); GDPt; Money Market Rate (MMRt); Discount Rate (DRt); Uncertainty Index (UI) and Consumer Price Index (CPIt). Diagnostic statistics; normality test (JarqueeBera test); heteroscedasticity test (Breusche Pagane Godfrey test); serial correlation (BreuscheGodgrey LM test); and multicollinearity test (centered inflation factor test). The Wald test is conducted to evaluate 10 separate quantiles from q0.10 to q0.90 on the quantile slope equality. For QR, we only record 5 quant les estimation results describing extreme lower, medium and extreme upper quantiles in line with our emphasis and due to space constraints while we measured all other quantiles (i.e., q0.10 to q0.90).

Figure 5 shows the trends of different variables that are using in the OLS regression analysis. The variables show mixed trends with selected time periods of the study. The autocorrelation in military period with increasing and decreasing trends is presented in Figure 5. All the variables show mixed trends for the time period of 1996-2018. 
Gradients of the Objectiv e Function

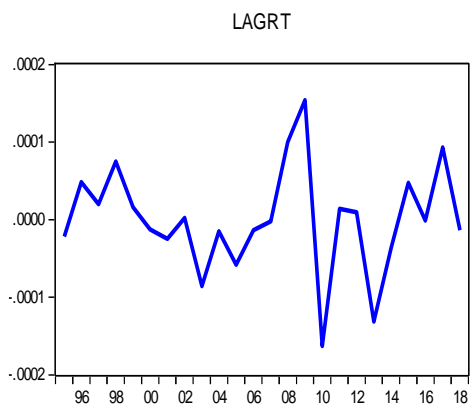

CPI
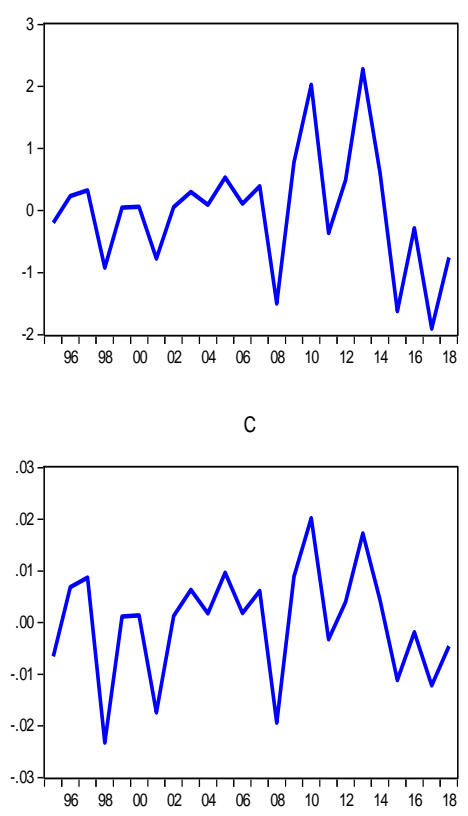

GDP

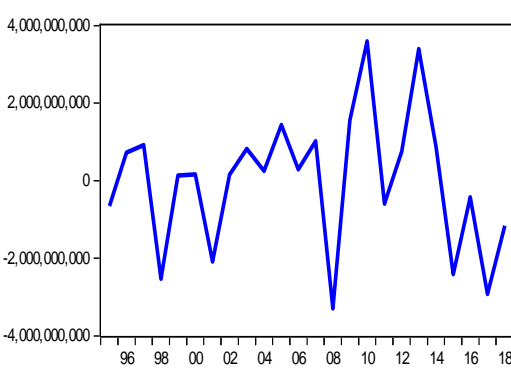

MMR

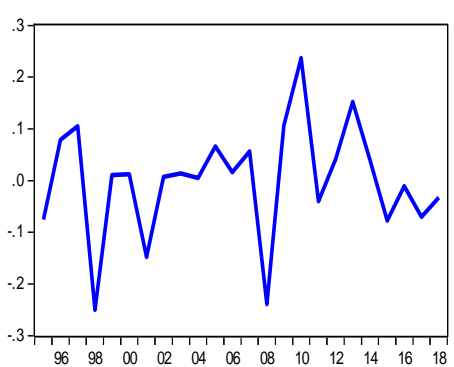

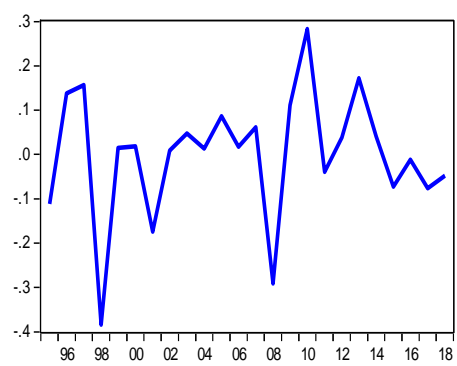

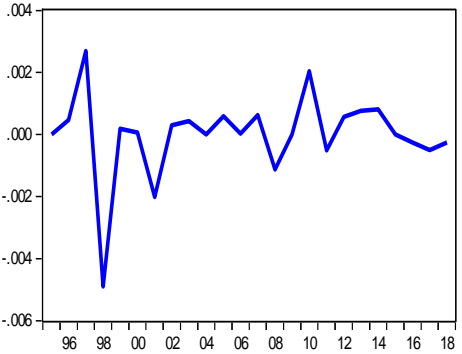

Figure 5. OLS Regression analysis

\section{Mix Trend of Future Returns and Volatility Returns}

Figure 6 shows the trend of returns and volatility returns for the time period of 1996-2019. The returns trend shows a constant behavior in comparison with volatility returns. The trend of volatility returns has an increasing and decreasing behavior.

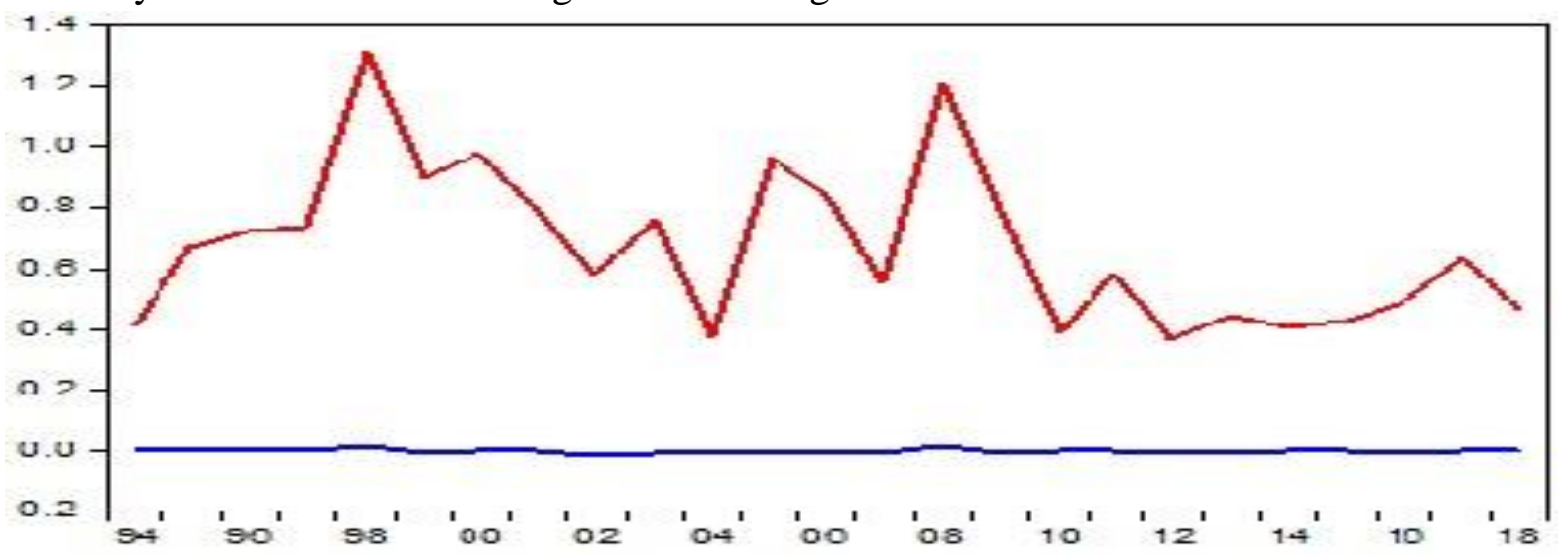

Figure 6. The trend of returns and volatility returns for the time period of 1996-2019 


\section{Future Returns and Volatility Returns Separately}

Figure 7 shows the returns and volatility returns separately. Both graphs show a mix trend with increasing and decreasing behavior.

\section{RT}

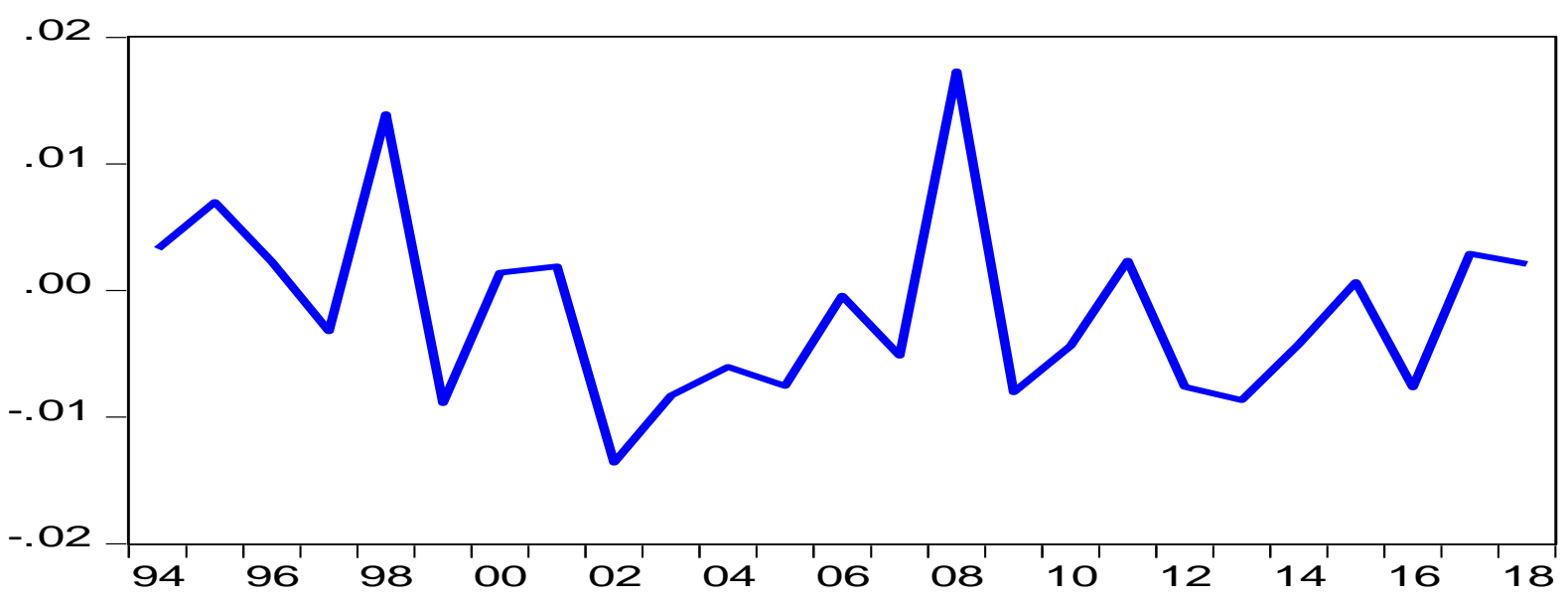

\section{RTV}

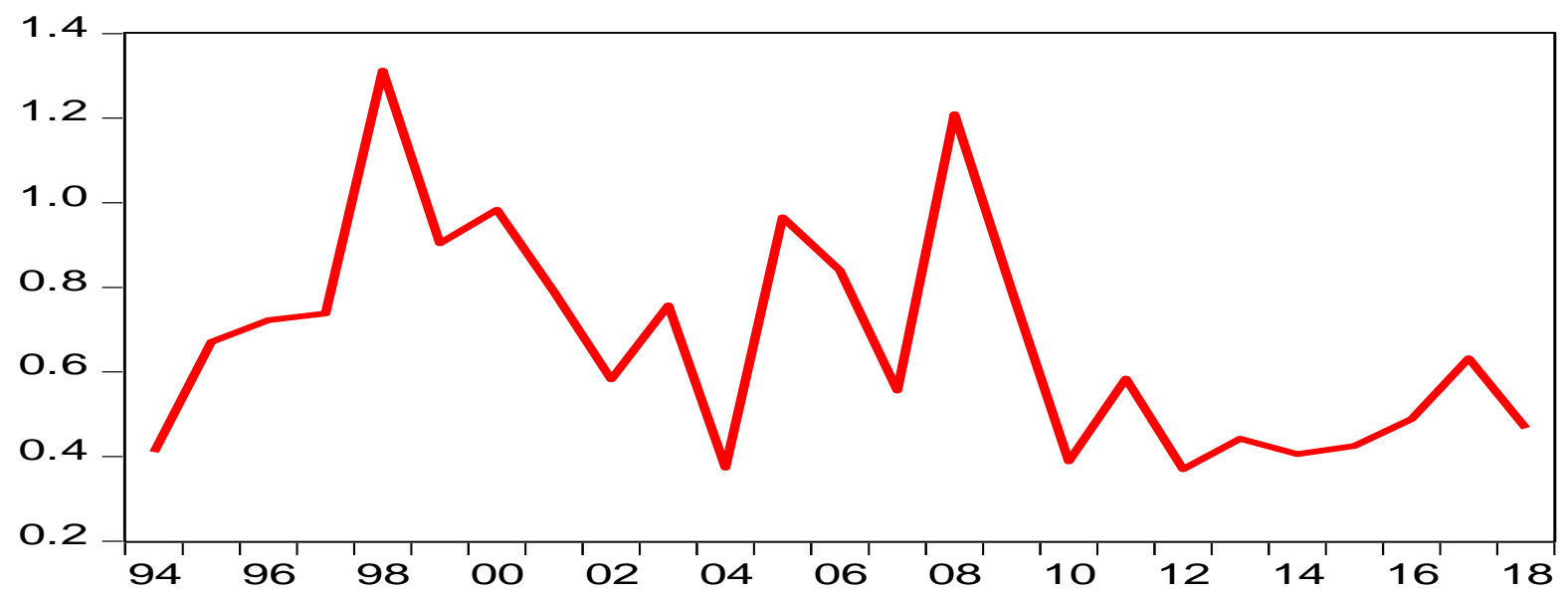

Figure 7. Returns (RT) and volatility returns (RTV).

\section{Discussion}

Lipset (1960) had developed the idea of political uncertainty and stated that a nation is considered to be stable whether it has been a stable and effective democracy or monarchy for 25 years. The contemporary economies school of thought has altered the concept of democratic chaos, and stock markets are an important medium for stimulating economic growth and a nation's ease. There are some limitations in the principle of market efficiency and the theory's existing empirical studies as behaviorists have suggested it is time to verify the socially reasonable investor's assumption on which the theory respites.

We contend with the "corrections" and cycles of stock price reflecting systemic biases in how investors use the details. Investors are hypothetical to put undue weight on current knowledge, concentrating, for example, myopically on short-term earnings while ignoring long-term prospects for businesses. Accordingly, stock prices are seen as highly unpredictable 
guidelines for allocating corporate capital and other essential decisions. Behavioral finance is not the solution to market theory's limitations, since the profit incentives generated by such an alleged myopia of investors seem fundamentally incompatible with competitive markets. They are way too large to be accurate, thereby casting doubt on the methods of science. In fact, our skepticism about these statements should be strengthened by the inability of the vast majority of qualified money managers to outperform market averages with some degree of consistence. The behavioral finance holds its own anomalies. The comprehensive proof of the earlier cited post-earnings-announcement idea suggests investors are putting too little, not too much, sleight on recent earnings details, showing that a hypothesis has anomalies is one thing, replacing it with an anomaly-free hypothesis is another. In the 1960s and 1970s, behavior lists have questioned the objectivity and openness of the study process, claiming that the process was slow to embrace rebel views.

\section{Comments: Benjamin Friedman}

It is no accident that work is in support of the principle of efficient markets. The business schools have emerged almost entirely from the country. This is both understandable and necessary from the private-interest perspective of these organizations. Financial markets in Pakistan face spirited pressures and the inspiring success of the past few years is much needed to be reinforced and built up. Attractive and satisfying is the path to a sustainable growth of domestic capital markets. The Government needs to make a firm commitment to developing Pakistan's financial system. Government regulators should serve as regulators to control market performance and take necessary measures to ensure the system is operating effectively where it is required. In order to make Pakistan's capital market the world's highest performing sector, it should be constant in this way. Moreover, better corporate governance is required to enhance the effectiveness of monetary policy accomplishment. Specific obligations are required to establish coordination among different regulatory agencies, such as the Ministry of Finance, Pakistan's Securities and Exchange Commission and Pakistan's State Bank.

\section{Conclusion}

The primary objective of this research is to analyze the effect of uncertainty on stock returns and risk-return agreements (volatility) across military and democratic phases, that is positive for the military phase as compared with two other sections. Results revealed that there is a substantial link between stock dividends and perceived good governance. Furthermore, there is a significant impact of these actions and events on KSE 100 INDEX stock returns being seen during the data period 1994 to 2018.

The findings of the study indicated that there is a significant connection between economic determinants during the military phase. On the other hand, two other mechanisms known as the aggregate and Electoral mechanism have an insignificant relationship. The Political Instability and economic determinants presented considerable credible evidence to support the relationship between political uncertainty and growth. Although, according to these evidences, the essence of the relation is mixed in terms of causality direction between macroeconomic variables and political uncertainty. These points guide research to the notion of political instability reducing the development of ongoing long-term ventures and causing radical economic revolutions (Asteriou \& Price, 2001). 
Feng (1997) also suggested that it has an opposite impact on country development if there is a change of government or constitution. Moreover, Bussie and Mulder (2000) have shown that political instability affects economic insecurity in low-reserve countries significantly. From various economists, academics, and financial analysts' views and research reports, the claim that events have a negative effect on prices and the markets showed a bullish trend to such events depends on the nature and severity of the case.

This study was conducted to check whether there is an effect of uncertainty on macroeconomic variables (CPI, GDP, MMR, DR) with respect to Pakistan Stock Market volatility and volatility returns. Discount rate, Money Market rate, CPI, GDP are the macroeconomic variables selected to check if there is any uncertainty effect on all index returns of KSE 100. By using OLS and QR techniques, we monitored stock return volatility and riskreturn on segmented stock market outcomes in Pakistan. The paper focused on understanding behavioral risks that will also ensure fair fundamental stock market valuation and successful financial market outcomes. This risk may manifest in periods of volatility and could be directly affected by investor conduct, capital allocation. The studies suggest that policy decisions have a direct impact on the stock market and should comprise of the political forces in their portfolio, which are often influenced by their event-based financial performance. An atmosphere which is economically weak could severely undermine development.

\section{References}

Abbas, A., Ahmed, E., \& Husain, F. (2019). Political and economic uncertainty and investment behaviour in Pakistan. The Pakistan Development Review, 58(3), 307-331.

Addo, A., \& Sunzuoye, F. (2013). The impact of treasury bill rate and interest rate on the stock market returns: Case of Ghana stock exchange. European Journal of Business and Economics, 8(2).

Ahir, H., Bloom, N., \& Furceri, D. (2018). The world uncertainty index. SSRN, 3275033.

Alam, M. D., \& Uddin, G. (2009). Relationship between interest rate and stock price: Empirical evidence from developed and developing countries. International Journal of Business and Management, 4(3), 43-51.

Ali, H. (2014). Impact of interest rate on stock market; evidence from Pakistani market. Journal of Business and Management, 16(1), 64-69.

Ambrosio, F. J. (2007). An evaluation of risk metrics. Vanguard, Investment Counseling.

Aryeetey, E., Baah-Nuakoh, A., Duggleby, T., Hettige, H., \& Steel, W. F. (1994). Supply and demand for finance of small enterprises in Ghana. The World Bank.

Asteriou, D., \& Price, S. (2001). Political instability and economic growth: UK time series evidence. Scottish Journal of Political Economy, 48(4), 383-399.

Belanová, K. (2014). Real options approach as a new view of investment. Ekonomické Rozhl'ady/ Economic Review, (43)3.

Boyd, J. H., Levine, R., \& Smith, D. B. (2000). The impact of inflation on financial sector development. Journal of Economic Literature, 31, 1-19.

Carlton, P. L. (1983). A primer of behavioral pharmacology: Concepts and principles in the behavioral analysis of drug action. New York: WH Freeman.

Carruth, A., Dickerson, A., \& Henley, A. (2000). What do we know about investment under uncertainty? Journal of Economic Surveys, 14(2), 119-154. 
Chen, N. F., Roll, R., \& Ross, S. A. (1986). Economic forces and the stock market. Journal of Business, 383-403.

Clark, E., Masood, O., \& Tunaru, R. (2008). The effect of political events on the Pakistan stock exchange 1947-2001. Investment Management and Financial Innovations, 5(3), 101-110.

Davidson, P. (1996). Reality and economic theory. Journal of Post Keynesian Economics, 18(4), 479-508

Demirgüç-Kunt, A., \& Levine, R. (1996). Stock markets, corporate finance, and economic growth: an overview. The World Bank Economic Review, 10(2), 223-239.

Esqueda, O. A., Assefa, T. A., \& Mollick, A. V. (2012). Financial globalization and stock market risk. Journal of International Financial Markets, Institutions and Money, 22(1), 87-102.

Feng, Y. (1997). Democracy, political stability and economic growth. British Journal of Political Science, 391-418.

Fernandez, R., \& Rodrik, D. (1991). Resistance to reform: Status quo bias in the presence of individual-specific uncertainty. The American Economic Review, 1146-1155.

Gans, J., King, S., Stonecash, R., \& Mankiw, N. G. (2011). Principles of economics. Cengage Learning.

Greenwood, J., \& Smith, B. D. (1997). Financial markets in development, and the development of financial markets. Journal of Economic Dynamics and Control, 21(1), 145-181.

Haroon, M. A., \& Jabeen, H. (2013). Impact of macro-economic variables on share price behavior of Karachi stock exchange. Pakistan Journal of Commerce and Social Sciences, 7(3), 493-504.

Hibbs, Jr., D. A. (1977). Political parties and macroeconomic policy. The American Political Science Review, 1467-1487.

Hussain, F., \& Qasim, M. A. (1997). The Pakistani equity market in 50 years: a review. The Pakistan Development Review, 863-872.

Ilahi, I., Ali, M., \& Jamil, R. A. (2015). Impact of macroeconomic variables on stock market returns: A case of Karachi stock exchange. SSRN, 2583401.

Jameel, K., \& Hayee, S. A. (2017). Macroeconomic variables and Stock Market liquidity: The case of Pakistan Stock Exchange. Journal of Business Administration and Management Sciences, 1(2), 45-54.

Janor, H., Halid, N., \& Rahman, A. A. (2005). Stock market and economic activity in Malaysia. Investment Management and Financial Innovations, 2(4), 116-123.

Jayasundara, J. M. D. P., Rathnayake, R. M. A. K., \& Fernando, P. J. S. (2019). Impact of macroeconomic variables on stock market performances: Evidence from Sri Lanka. Sri Lanka Journal of Business Economics, 8(1).

Julio, B., \& Yook, Y. (2012). Political uncertainty and corporate investment cycles. The Journal of Finance, 67(1), 45-83.

Kandel, S., Ofer, A. R., \& Sarig, O. (1993). Learning from trading. The Review of Financial Studies, 6(3), 507-526.

Khalid, W., \& Khan, S. (2017). Effects of macroeconomic variables on the stock market volatility: the Pakistan experience. Global Journal of Management and Business Research. Retrieved from https://www.journalofbusiness.org/index.php/GJMBR/article/view/2301

Koenker, R. (2015). Quantile Regression in R: a Vignette. Retrieved from https://cran. r-project. org/web/packages/quantreg/vignettes/rq. pdf

Koenker, R. (2017). Quantile regression: 40 years on. Annual Review of Economics, 9, 155-176.

Koenker, R., \& Hallock, K. F. (2001). Quantile regression. Journal of Economic Perspectives, 15(4), 143-156.

Kibria, U., Mehmood, Y., Kamran, M., Arshad, M. U., Perveen, R., \& Sajid, M. (2014). The impact of macroeconomic variables on stock market returns: A case of Pakistan. Research Journal of Management Sciences, 7(8), 1-7.

Lei, X., \& Wisniewski, T. P. (2018). Democracy and stock market returns. SSRN, 3198561.

Lipset, S. M. (1960). Political man. London: William Heinemann Limited.

Malik, A., \& Temple, J. R. (2009). The geography of output volatility. Journal of Development Economics, 90(2), $163-178$.

Mohtadi, H., \& Agarwal, S. (2001). Stock market development and economic growth: Evidence from developing countries. Retrieved from http//www. uwm. edu/mohadi/PA-4-01. pdf.

Nazir, M. S., Younus, H., Kaleem, A., \& Anwar, Z. (2014). Impact of political events on stock market returns: empirical evidence from Pakistan. Journal of Economic and Administrative Sciences, 30(1), 60-78. 
Pattillo, C. (1998). Investment, uncertainty, and irreversibility in Ghana. Staff Papers, 45(3), 522-553.

Pindyck, R. S., \& Solimano, A. (1993). Economic instability and aggregate investment. NBER Macroeconomics Annual, 8 , 259-303.

Rizwan, M. F., \& Khan, S. U. (2007). Stock return volatility in emerging equity market (Kse): the relative effects of country and global factors. International Review of Business Research Papers, 3(2), 362-375.

Sajjad, S. I., Jan, S. U., Saddat, M., \& ur Rehman, I. (2012). Exploring the nexus; stock market, T. bills, inflation, interest rate and exchange rate. Journal of Economics and Behavioral Studies, 4(7), 384-389.

Schwert, G. W. (1989). Why does stock market volatility change over time? The Journal of Finance, 44(5), 1115-1153.

Schwert, G. W., \& Seguin, P. J. (1990). Heteroskedasticity in stock returns. The Journal of Finance, 45(4), 1129-1155.

Simon, C. P., \& Blume, L. (1994). Mathematics for economists (Vol. 7). New York: Norton.

Sjaastad, E., \& Bromley, D. W. (1997). Indigenous land rights in Sub-Saharan Africa: Appropriation, security and investment demand. World Development, 25(4), 549-562.

Stewart, D. B., \&Venieris, Y. P. (1985). Sociopolitical instability and the behavior of savings in less-developed countries. The Review of Economics and Statistics, 557-563.

Tabassam, A. H., Hashmi, S. H., \& Rehman, F. U. (2016). Nexus between political instability and economic growth in Pakistan. Procedia-Social and Behavioral Sciences, 230, 325-334. 